\title{
Tolerance to Endotoxin-induced Expression of the Interleukin-1 $\beta$ Gene in Blood Neutrophils of Humans with the Sepsis Syndrome
}

\author{
Charles E. McCall, Lynell M. Grosso-Wilmoth, Karen LaRue, Rosa N. Guzman, and Sue L. Cousart \\ Section on Infectious Diseases, Department of Medicine, Wake Forest University Medical Center, Winston-Salem, North Carolina 27157
}

\begin{abstract}
The induction of genes of host cells stimulated by microbial products such as endotoxin and the tolerance of cells to endotoxin excitation play critical roles in the pathogenesis of microbial-induced acute disseminated inflammation with multiorgan failure (the sepsis syndrome). One gene that is induced in phagocytic cells by endotoxin and that appears to play an essential role in the pathogenesis of the sepsis syndrome is IL- $1 \beta$. We report here that blood neutrophils (PMN) of patients with the sepsis syndrome (sepsis PMN) are consistently tolerant to endotoxin-induced expression of the IL-1 $\beta$ gene, as determined by decreased synthesis of the IL- $1 \beta$ protein and reductions in IL-1 $\beta$ mRNA. This down-regulation of the IL- $1 \beta$ gene in sepsis PMN occurs concomitant with an upregulation in the constitutive expression of the type 2 IL-1 receptor (IL-1R2). These phenotypic changes do not persist in $\mathrm{PMN}$ of patients recovering from the sepsis syndrome. Tolerance has stimulus and response specificity since sepsis PMN tolerant to endotoxin can respond normally to Staphylococcus aureus stimulation of IL$1 \beta$ production and they normally secrete elastase. Uninfected patients with severe trauma or shock from causes are not tolerant to endotoxin and tolerance is not limited to patients infected with Gram-negative bacteria. The mechanism responsible for tolerance involves pretranslational events and is not due to loss of the CD14 surface protein, a receptor required for endotoxin induction of IL-1 $\beta$ in PMN. The physiological significance of the tolerance to endotoxin and increased expression of IL-1R2 on sepsis PMN is unknown, but may represent an attempt by the host to protect itself from the deleterious effects of disseminated inflammation. (J. Clin. Invest. 1993. 91:853-861.) Key words: shock • inflammation • CD14 • interleukin-1R2 • lipopolysaccharide
\end{abstract}

\section{Introduction}

Acute disseminated intravascular inflammation with multiorgan failure may occur during the course of various infections, a process often referred to as the sepsis syndrome (for review see reference 1). The sepsis syndrome is the major cause of mortality in critical care units in this country; it has a mortality rate of 40 to $70 \%$ and kills over 100,000 people in this country each

Address correspondence to Charles E. McCall, M. D., Section on Infectious Diseases, Department of Medicine, Bowman Gray School of Medicine, Medical Center Boulevard, Winston-Salem, NC 27157.

Received for publication 14 April 1992 and in revised form 14 September 1992.

J. Clin. Invest.

(C) The American Society for Clinical Investigation, Inc.

0021-9738/93/03/0853/09 \$2.00

Volume 91, March 1993, 853-861 year $(2,3)$. Although there has been little improvement in the mortality of sepsis syndrome since it was defined as a clinical entity, knowledge of the pathogenesis of this frequently lethal process has been rapidly increasing (1). From this new information, new and promising therapies derived from studies of the pathogenic mechanisms responsible for the sepsis syndrome are emerging (3-6).

The sepsis syndrome in humans is associated with the expression of a number of genes coding for various potentially autotoxic cytokines, including TNF $\alpha$ (7), IL- $1 \alpha-\beta$ (8), IL-6 (9), $\gamma$ interferon $(10)$, and IL-8 $(10,11)$. Of these, IL-1 and TNF $\alpha$ have been identified as essential elements in the pathogenesis of sepsis syndrome in animals (for review see reference 12). The specific cell types producing these cytokines during the sepsis syndrome have not been identified in humans, but many cells are capable of synthesizing these proteins after stimulation with microbial toxins or host-derived inflammatory mediators. The human blood neutrophil (PMN) is one such cell.

We recently reported that human blood neutrophils $(\mathrm{PMN})$ rapidly synthesize both IL- $1 \alpha$ and $-\beta$ when stimulated by endotoxin (13). IL-1 $\beta$ is released from endotoxin-stimulated PMN, but IL- $1 \alpha$ remains associated with the cell. Although the capacity of PMN to translate IL-1 mRNA is less than that of human blood mononuclear cells (13), the predominance of PMN in the circulation and at local sites of acute inflammation could provide a major source of IL-1, as well as TNF $\alpha$ (14).

Although the sepsis syndrome can be induced by a variety of infecting microorganisms and a similar syndrome can be seen in the absence of detectable infection (e.g., severe trauma and acute pancreatitis) (1), the lipopolysaccharide endotoxin of Gram-negative microorganisms is a particularly important cause of the sepsis syndrome in animals and humans and a potent stimulus of cells in vitro (for review see reference 15). Cells and whole organisms can also become tolerant to stimulation by endotoxin (16). Tolerance or adaptation to endotoxin occurs in at least two forms (17). One type of tolerance takes 1-2 wk to develop and requires the production of specific antibodies (18); a second form of tolerance develops within hours and is characterized by desensitization of cells to stimulation by endotoxin (19). This early adaptation or tolerance to endotoxin follows stimulation of whole organisms or cells by either low concentrations of endotoxin, TNF $\alpha$, or IL-1 (20-22). Cells or whole organisms tolerant to endotoxin can withstand a challenge of endotoxin many times above that that is usually stimulatory to cells and lethal to whole organisms (16). Crosstolerance can occur between endotoxin and TNF $\alpha$ or IL-1 (20, 23-25).

Studies of endotoxin tolerance induced in vitro (26-29) and in vivo $(24,30,31)$ in animals have shown a decrease in the production of several cytokines by macrophages, including IL-1, TNF $\alpha$, and IL- 6 . We are aware of only two studies of tolerance to endotoxin performed in humans. Tolerance to en- 
dotoxin-induced synthesis of TNF $\alpha$, IL- $1 \beta$, and IL- 6 of blood monocytes obtained from humans with the sepsis syndrome was recently reported (32). Another recent study found tolerance to endotoxin-induced synthesis of putative IL-1 bioactivity in monocytes from two children with Hemophilus influenza meningitis (33). To our knowledge, there are no reports of in vitro or in vivo endotoxin tolerance of animal or human PMN.

We recently reported that blood PMN obtained from patients with sepsis syndrome have marked and consistent elevations in expression of the type 2 interleukin- 1 receptor (IL1R2) (34), as well as one or both of the receptors to TNF $\alpha$ (35). Here, we report a study of IL- $1 \beta$ gene expression in blood PMN obtained from patients with sepsis syndrome. We find that sepsis PMN are consistently tolerant to endotoxin-induced expression of the IL- $1 \beta$ gene. The mechanism responsible for endotoxin tolerance has not been precisely defined, but it is pretranslational and it does not involve loss of the CD14 receptor for endotoxin from the surface of sepsis PMN.

\section{Methods}

\section{Patients}

Patients admitted to the Wake Forest University Medical Center were selected for entry into the study on the basis of the criteria shown in Table I; these are slight modifications of the criteria of Bone (36). Exclusions included patients with leukocyte counts $<1,000 / \mathrm{mm}^{3}$ and patients with known human immunodeficiency virus infection. The study was endorsed by The Internal Review Board for Clinical Research of the Medical Center. Samples of heparinized venous or arterial blood were drawn and delivered to the lab immediately. A venous blood sample obtained from healthy adults served as a source of normal cells; the control blood was drawn within 15 min of the patient blood and both samples were handled and processed identically. A chart review and data analysis was conducted on all patients after completion of the study.

\section{PMN isolation}

Human PMN were isolated from heparinized venous blood obtained from normal adult volunteers or patients by Plasma Gel (Cellular Products, Inc., Buffalo, NY) sedimentation followed by centrifugation in Isolymph (Gallard-Schlesinger Chemical Mfg. Corp., Carle Place, NY) as previously described (34). Contaminating red cells were removed by hypotonic lysis and isolated PMN (97-99\% pure) were resuspended in culture medium (RPMI 1640) (Gibco BRL, Gaithersburg, MD) containing 5\% low-endotoxin bovine FCS (Hyclone Laboratories Inc., Logan, UT), $40 \mu \mathrm{g} / \mathrm{ml}$ of gentamicin (Lyphomed Inc., Rosemont, IL), and $25 \mathrm{mM}$ Hepes (Calbiochem Corp., LaJolla, CA) at $2 \times 10^{7} \mathrm{PMN} /$ $\mathrm{ml}$ for binding studies and $3 \times 10^{6} \mathrm{PMN} / \mathrm{ml}$ for IL- $1 \beta$ production. Pyrogen-free reagents were used wherever possible and all solutions were routinely monitored for endotoxin contamination by the Limulus amebocyte lysate assay (sensitivity $\sim 10 \mathrm{pg} / \mathrm{ml}$ ). The percentage of immature forms of PMN after isolation did not differ significantly from the whole blood differential when using this method. PMN from both normal controls and patients remained $>90 \%$ viable over the course of study as determined by exclusion of trypan blue dye.

\section{$I L-1 \beta$ synthesis}

PMN $\left(3 \times 10^{6} / \mathrm{ml}\right)$ were incubated in the presence or absence of 100 $\mathrm{ng} / \mathrm{ml}$ (unless indicated) 0111:B4 Escherichia coli endotoxin (Difco Laboratories Inc., Detroit, MI) or an in-house strain of Staphylococcus aureus (at a ratio of $\sim 20: 1$ microbes to PMN) in a 24-well tissue culture plate (Becton-Dickinson \& Co., Oxnard, CA); cells were not shaken or rocked. After incubation in culture medium for $8 \mathrm{~h}$ at $37^{\circ} \mathrm{C}$ in $5 \% \mathrm{CO}_{2}$, an equal volume of a lysis buffer $(0.16 \mathrm{M} \mathrm{NaCl}, 0.02 \mathrm{M}$ deoxycholate, $1 \%$ Triton, $0.1 \%$ SDS, $0.01 \mathrm{M}$ Tris, pH 7.4, with apro-
Table I. Clinical Criteria for Enrollment of Subjects with the Sepsis Syndrome

a) Presumptive or documented primary focus of infection

b) Evidence of acute disseminated inflammation (two or more of the following): (a) fever $\left(>38^{\circ} \mathrm{C}\right.$ or $100.4^{\circ} \mathrm{F}$, rectal) or hypothermia $\left(<36^{\circ} \mathrm{C}\right.$ or $96.8^{\circ} \mathrm{F}$, rectal); (b) tachycardia otherwise unexplained (heart rate $>90$ beats per $\min$ ); (c) tachypnea otherwise unexplained (respiratory rate $>20$, or $>10$ liter/min if on mechanical ventilation, or $\mathrm{P}_{\mathrm{a}} \mathrm{CO}_{2}<20 \mathrm{mmHg}$ during unassisted respiration); (d) absolute leukocytosis $\left(>12,000 / \mathrm{mm}^{3}\right)$ or leukopenia $\left(<3,000 / \mathrm{mm}^{3}\right)$, or $\geq 20 \%$ immature forms of PMN

c) Evidence of multiorgan dysfunction (hypotension or pressor dependency alone or at least two of the other signs of organ failure):

Hypotension ( $<90 \mathrm{mmHg}$ systolic arterial pressure or a $25 \%$ drop of baseline blood pressure)

Increased cardiac index $\left(>4\right.$ liter/min per $\left.\mathbf{M}^{2}\right)$ or decreased systemic vascular resistance $\left(<800 \mathrm{dyn} / \mathrm{sec}\right.$ per $\mathrm{cm}^{-5}$ )

Hypoxemia (arterial $\mathrm{pO}_{2}<75 \mathrm{mmHg}$ on room air or an abnormal ratio of $\mathrm{paO}_{2} / \mathrm{FiO}_{2}[<280]$ in the absence of other pulmonary or cardiovascular causes)

Acute renal impairment (oliguria $<30 \mathrm{ml} / \mathrm{h} \geq 1 \mathrm{~h}$ )

Metabolic acidosis (elevated serum lactate [ $>2.2 \mathrm{mg} / \mathrm{dl}]$, or decreased serum bicarbonate [ $\leq 15 \mathrm{meq} /$ liter] or anion gap of $>15$ [base deficit $\geq 5$ $\mathrm{mEq} /$ liter] unless there is chronic renal failure)

Abnormal mentation (in relation to patient's baseline, usually measured by deterioration in the Glasgow Coma Score at least one point below baseline)

Disseminated intravascular coagulation (fibrin degradation fragments $>1: 40$; D-dimers $>2.0$; platelet count $<25 \%$ of a previously documented value).

tinin and pepstatin) was added to lyse the cells. These lysates were frozen at $-20^{\circ} \mathrm{C}$ and assayed for IL- $1 \beta$ by an ELISA (Cistron Corp., Pine Brook, NJ) with a sensitivity of $\sim 25 \mathrm{pg} / \mathrm{ml}$.

\section{$I L-1 \beta$ mRNA analysis}

$\operatorname{Poly}(A)^{+}$RNA isolation. RNA was isolated by using modifications of the methods described (37). Briefly, PMN were centrifuged and the cell pellet was resuspended in $6 \mathrm{ml}$ of lysis buffer ( $4 \mathrm{M}$ guanidinium thiocyanate; $25 \mathrm{mM}$ sodium citrate, $\mathrm{pH} 7.0 ; 0.1 \mathrm{M}$ 2-mercaptoethanol; and $0.5 \% \mathrm{~N}$-lauroylsarcosine) followed by $0.6 \mathrm{ml}$ of $2 \mathrm{M}$ sodium acetate, equal volumes of water-saturated phenol, and $1.6 \mathrm{ml}$ of $49: 1$ chloroform/isoamyl alcohol. The mixture was vortexed between each addition and then incubated on ice for $15 \mathrm{~min}$, spun at $9,000 \mathrm{~g}$ at $4^{\circ} \mathrm{C}$ for 30 min, the aqueous phase was removed, and the RNA was precipitated with 1 vol isopropanol. The precipitated RNA was resuspended in binding buffer $(0.5 \mathrm{M} \mathrm{NaCl}$; $0.01 \mathrm{M}$ Tris, $\mathrm{pH} 7.5 ; 1 \mathrm{mM}$ EDTA; and $0.5 \%$ SDS) and mixed with a slurry of oligo(dT)cellulose (Boehringer Mannheim Corp., Indianapolis, IN). A column was poured in a $0.1 \mathrm{M}$ $\mathrm{NaCl}, 0.01 \mathrm{M}$ Tris buffer at $\mathrm{pH} 7$, containing $1 \mathrm{mM}$ EDTA and $0.5 \%$ SDS. Poly $(\mathrm{A})^{+} \mathrm{RNA}$ was eluted with a $0.01 \mathrm{M}$ Tris buffer at $\mathrm{pH} 7$, containing $1 \mathrm{mM}$ EDTA and $0.05 \%$ SDS.

Northern blot analysis. Equal amounts of poly (A) ${ }^{+}$RNA were electrophoresed through $1 \%$ agarose, $6.6 \%$ formaldehyde gels in $1 \times$ 3-( $N$-morpholino)propanesulfonic acid (MOPS) buffer (0.02 M MOPS, $5 \mathrm{mM}$ sodium acetate, and $1 \mathrm{mM}$ EDTA) and diffusion blotted onto Genescreen (New England Nuclear, Boston, MA) as described by the manufacturer.

The plasmid containing huIL- $1 \beta$ cDNA insert ( 570 bp SstI to PvuII restriction in pGEMI was kindly supplied by Steven Gillis, Immunex, Seattle, WA ). To generate an antisense RNA probe for Northern analysis, the plasmid was cut with EcoR 1 and transcribed in vitro (38) with SP6 RNA polymerase in the presence of $\left[\alpha{ }^{32} \mathrm{P}\right] \mathrm{CTP}$ (Amersham Corp., Arlington Heights, IL). The IL- $1 \beta$ insert was cut with SstI and BamHI and contained a specific activity of $1 \times 10^{8} \mathrm{cpm} / \mu \mathrm{g}$. Genescreen filters were prehybridized for $30 \mathrm{~min}$ at $65^{\circ} \mathrm{C}$ in $50 \%$ formamide; $0.25 \mathrm{M} \mathrm{NaPO}_{4}$, pH 7.2; $0.25 \mathrm{M} \mathrm{NaCl} ; 1 \mathrm{mM}$ EDTA; 7\% SDS; and $5 \%$ polyethylene glycol. After prehybridization, filters were main- 
tained for $24 \mathrm{~h}$ at $65^{\circ} \mathrm{C}$ in the same prehybridization solution containing $1 \times 10^{6} \mathrm{cpm} / \mathrm{ml}$ of ${ }^{32} \mathrm{P}$-labeled riboprobe. Filters were washed twice in $2 \times \mathrm{SSC}$ for $15 \mathrm{~min}$ at room temperature. The $\beta$-actin cDNA control (Clontech, Palo Alto, CA) was labeled by nick-translation with $[\alpha]-{ }^{32} \mathrm{P}$ $\operatorname{dCTP}(3,000 \mathrm{Ci} / \mathrm{mmol}$; New England Nuclear $)$ to a specific activity of $1 \times 10^{8} \mathrm{cpm} / \mu \mathrm{g}$ of DNA. Genescreen filters were hybridized as described by Virca et al. (39). Autoradiography of hybridized Genescreen membranes was done at $-70^{\circ} \mathrm{C}$ using XAR-5 film (Eastman Kodak Co., Rochester, NY) and Duplex Cronex Lightning Plus intensifying screen (EA, Wilmington, DE). Autoradiographs were scanned using a laser densitometer (Ultrascan XL; LKB Instruments Inc., Bromma, Sweden ).

\section{${ }^{125}$ I IL-1 $\alpha$ binding assay for the IL-IR2 of PMN}

Recombinant human IL-1 $\alpha$ (a gift from Dr. Peter Lomedico, Hoffmann-LaRoche, Nutley, NJ or Drs. Steve Gillis and Steve Dower, Immunex Corp.) was radioiodinated with carrier-free Na- ${ }^{125}$ I ( Amersham Corp.) by using Enzymobeads (Bio-Rad Laboratories, Richmond, CA) as previously described by Paganelli-Parker et al. (40). The ${ }^{125}$ IL-l $\alpha$ among preparations exhibited a specific activity of 30 to $70 \mu \mathrm{Ci} / \mu \mathrm{g}$ protein; this labeling procedure maintains $\sim 90 \%$ of IL- $1 \alpha$ bioactivity as measured by the D10.G4.1 murine comitogen assay. The radiolabeled protein was stored at $4^{\circ} \mathrm{C}$ and used within $\sim 4 \mathrm{wk}$.

PMN from patients or controls and ${ }^{125}$ I IL- $1 \alpha$ at varying concentrations were incubated in culture medium in a total volume of $150 \mu \mathrm{l}$ for $4 \mathrm{~h}$ at $4^{\circ} \mathrm{C}$ on a rocker platform (34). Nonspecific binding was measured by incubations of cells in the presence of $\geq 100$-fold molar excess of unlabeled recombinant human rhuIL- $1 \alpha$. Samples were performed in triplicate with a variation in triplicate binding of $<10 \%$ in most instances. Cell-bound and free ${ }^{125}$ IL- $1 \alpha$ were separated by centrifugation through $100 \mu \mathrm{l}$ of a silicone oil mixture (one part Thomas oil to two parts Gallard-Schlesinger oil). Tips containing pelleted cells and bound labeled protein were then counted on a gamma counter and Scatchard analysis of saturation curves was used to determine the $K_{\mathrm{d}}$ and receptor sites per cell.

\section{Flow cytometry analysis of the CD14 receptor}

$\mathrm{PMN}$ were isolated and then suspended in binding medium at a concentration of $2 \times 10^{6}$ cells $/ \mathrm{ml}$. For evaluation of CD14, cells were incubated at $4^{\circ} \mathrm{C}$ for $30 \mathrm{~min}$ with either the phycoerythrin-conjugated monoclonal antibodies Leu M3 (Becton-Dickinson \& Co.) or MY 4 (Coulter Corp., Hialeah, FL), which recognize different epitopes of the CD14 receptor for lipopolysaccharide (41), or an isotype control IgG2a antibody (Becton-Dickinson \& Co.). PMN were then washed once, fixed in $4 \%$ paraformaldehyde, and washed again. Analysis was performed on a FACStar ${ }^{\text {plus }}$ (Becton-Dickinson \& Co.) and fluorescence intensity was expressed in $\log _{10}$ units per relative number of cells. The horizontal axis was set as a four log scale, with each 250 channels representing one log.

\section{Elastase analysis}

Elastase secretion by stimulated PMN was determined as described by Sklar et al. (42). This is a spectroscopic assay that measures cleavage of the artificial substrate MeO-SUC-Ala-Ala-Pro-Val-MCA (Peninsula Laboratories, Inc., Belmont, CA) after release of secretion of elastase from the primary granules of PMN. PMN $\left(2 \times 10^{6}\right)$ in $0.1 \%$ gelatin and Hanks' buffer were stimulated with $1 \mu \mathrm{M}$ FMLP in the presence of 5 $\mu \mathrm{g} / \mathrm{ml}$ of cytochalasin $\mathrm{B}$ for $5 \mathrm{~min}$ at $37^{\circ} \mathrm{C}$. The fluorescence generated by cleavage of $1 \times 10^{-5} \mathrm{M}$ MeO-SUC-Ala-Ala-Pro-Val-MCA to aminomethylcoumarin was measured using an SLM 8000 computer-interfaced spectrofluorometer (SLM Instruments, Inc., Urbana, IL) at an excitation of $380 \mathrm{~nm}$ with emission fluorescence monitored at $460 \mathrm{~nm}$. Secretion of elastase was expressed as the maximum slope (rate of cleavage of fluorogenic substrate) during the first $5 \mathrm{~min}$ of stimulation.

\section{Statistical analysis}

Nonpaired and paired two-tailed Student's $t$ tests were used to determine statistical significance.

\section{Results}

Synthesis of $I L-1 \beta$ by sepsis PMN. Synthesis of IL- $1 \beta$ was evaluated in blood PMN obtained from 24 patients with the sepsis syndrome and compared in parallel with normal PMN, with and without stimulation by endotoxin. The results are shown in Fig. 1 . No synthesis of IL- $1 \beta$ was observed in unstimulated normal or sepsis PMN, but all preparations of sepsis PMN had reductions in endotoxin-induced IL- $1 \beta$ synthesis in comparison with a parallel control. The difference in endotoxin-induced synthesis of IL- $1 \beta$ by normal and sepsis PMN as analyzed by the paired or nonpaired $t$ test was highly significant ( $P$ $<0.001$ ).

Our previous study of increased expression of IL-1R2 on sepsis PMN suggested that this phenotypic change in sepsis PMN might have specificity for the sepsis syndrome (34). Munoz et al. (32) recently found that, in contrast with patients with the sepsis syndrome, endotoxin tolerance of monocytes was not present in cells obtained from patients with hypotension from other causes (e.g., hemorrhage or myocardial failure ). To determine whether endotoxin tolerance of IL- $1 \beta$ synthesis is just the result of being critically ill, we evaluated patients with a similar level of disease severity (43), but without the presence of detectable infection. Most of these patients had severe trauma or shock without detectable infection. Table II provides a list of these patients with the type of illness and the quantity of IL- $1 \beta$ produced after stimulation with endotoxin. The mean level of IL- $1 \beta$ synthesized by this group was no different from that of normal subjects $(P>0.5)$.

To determine if endotoxin tolerance persists after reversal of the sepsis syndrome, we evaluated the endotoxin-induced synthesis of IL- $1 \beta$ during and after the reversal of hypotension in three patients. Fig. 2 shows that the tolerance to endotoxininduced synthesis of IL- $1 \beta$ was not present in PMN from patients who recovered from organ failure.

To ascertain whether tolerance was related to the concentration of endotoxin used to stimulate PMN, sepsis PMN were treated with concentrations of endotoxin (from 1 to $10^{5} \mathrm{ng}$ / $\mathrm{ml}$ ). Reduced synthesis of IL- $1 \beta$ was observed at all concentrations of endotoxin (Fig. 3). We also determined that the re-

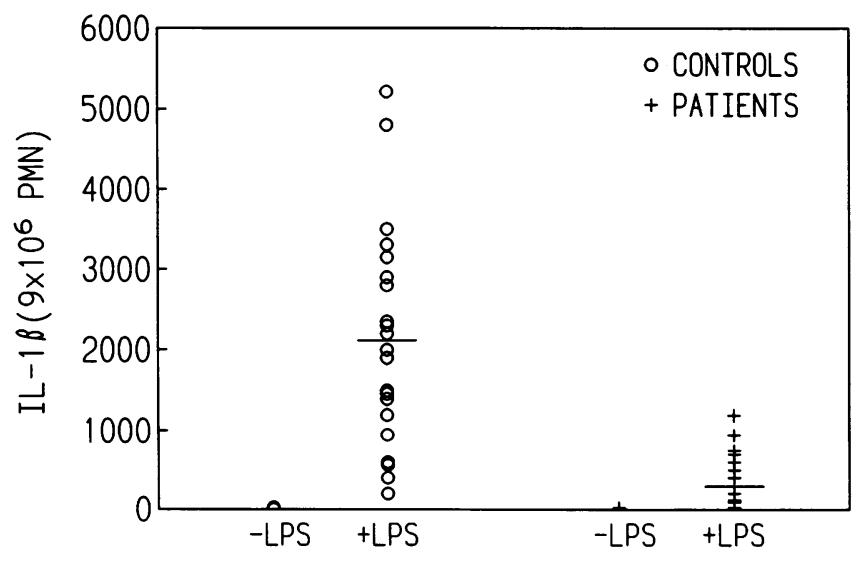

Figure 1. Endotoxin-induced synthesis of IL- $1 \beta$ in sepsis versus normal PMN. Isolated PMN were stimulated for $8 \mathrm{~h}$ at $37^{\circ} \mathrm{C}$ with 100 $\mathrm{ng} / \mathrm{ml}$ of $0111: \mathrm{B} 4$ E. coli endotoxin and IL- $1 \beta$ measured by ELISA. The cross-bar represents the mean of each group. Synthesis of IL-1 $\beta$ was always less in sepsis PMN than the normal PMN parallel control $(P<0.0001$ by the paired and $P<0.001$ by the nonpaired $t$ test $)$. 
Table II. Synthesis of IL-1ß by PMN of Patients with Severe Illness but Without Detectable Infection

\begin{tabular}{clc}
\hline Patient & \multicolumn{1}{c}{ Disease process } & IL-1 $\beta^{*}$ \\
\hline & & $p g / 9 \times 10^{\circ} \mathrm{cells}$ \\
1 & Trauma & 5,700 \\
2 & Trauma & 3,444 \\
3 & Trauma & 4,137 \\
4 & Trauma & 531 \\
5 & Trauma & 2,874 \\
6 & Trauma & 2,946 \\
7 & Trauma and burn & 492 \\
8 & Hypovolemic shock & 2,200 \\
9 & Cardiac shock & 2,000 \\
10 & 53\% burn & 1,100 \\
11 & Trauma & 1,500 \\
12 & Toxic erythema & 2,800 \\
& & \\
\hline
\end{tabular}

* Mean $\pm \mathrm{SD}=2,477 \pm 1,520$. Isolated PMN were stimulated as described for Fig. 1. The mean synthesis for this group was not signifcantly different from that of controls, as shown in Fig. 1.

duced synthesis of IL-1 $\beta$ was not related to the single time point routinely used in our assay; defective synthesis of IL-1 $\beta$ by sepsis PMN stimulated by endotoxin was present at all time points during 1 to $18 \mathrm{~h}$ of incubation with endotoxin (not shown).

We have observed that $S$. aureus is an equally potent stimulus for IL- $1 \beta$ production in normal PMN and that the kinetics of IL- $1 \beta$ production are similar to those induced by endotoxin (not shown). Using S. aureus, we tested the premise that tolerance of IL-1 $\beta$ synthesis has stimulus specificity for endotoxin. Fig. 4 shows that sepsis PMN tolerant to endotoxin can respond normally to stimulation of IL- $1 \beta$ synthesis induced by $S$. aureus. No statistical difference was observed between sepsis

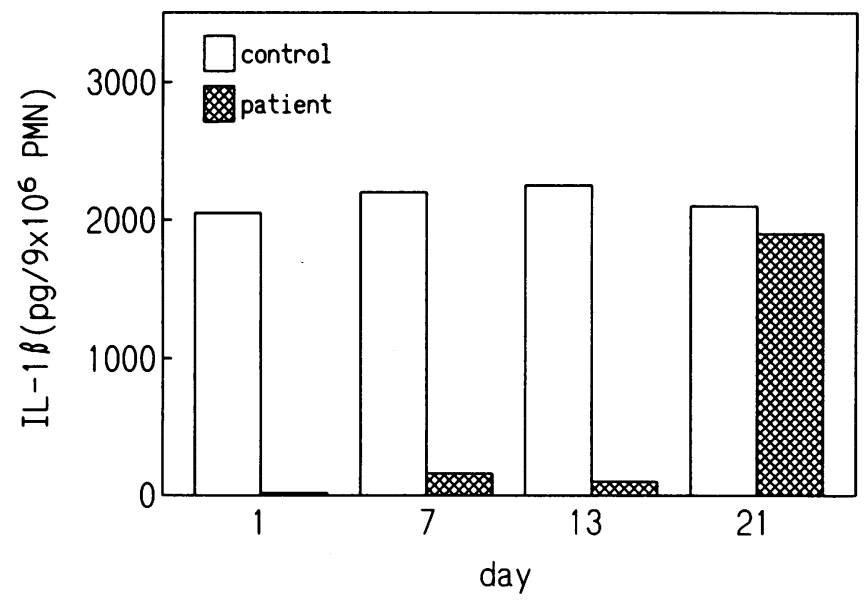

Figure 2. Reversal of tolerance to endotoxin-induced IL- $1 \beta$ synthesis in a patient recovering from sepsis syndrome. IL- $1 \beta$ was measured by ELISA in sepsis PMN and normal PMN during the hypotensive phase of a patient with the sepsis syndrome and $\sim 5 \mathrm{~d}$ after recovery from hypotension. Experimental conditions were like those of Fig. 1. This figure exhibits one of three experiments, all of which showed that IL- $1 \beta$ synthesis by PMN was normal after recovery from the sepsis syndrome.

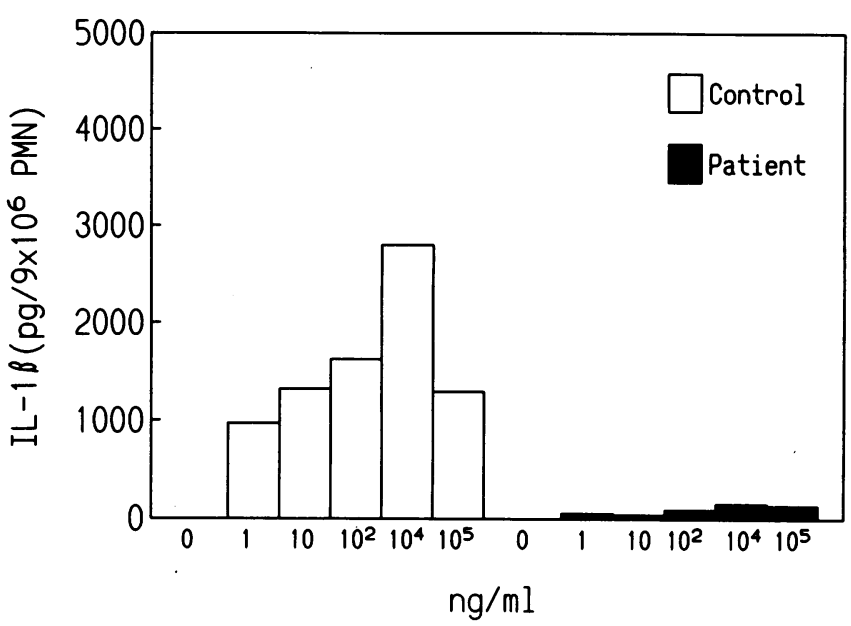

Figure 3. Synthesis of IL- $1 \beta$ sepsis versus normal PMN after stimulation with varying concentrations of endotoxin. Sepsis PMN and normal PMN were stimulated for $8 \mathrm{~h}$ at $37^{\circ} \mathrm{C}$ with varying concentrations of 0111 :B4 E. coli endotoxin and IL-1 $\beta$ measured by ELISA.

versus normal PMN, as determined by paired or nonpaired $t$ test.

Concomitant decreases in endotoxin-induced synthesis of $I L-1 \beta$ and increases in expression of $I L-1 R 2$. We previously reported that the number of IL-1R2 expressed on sepsis PMN is consistently 6-10-fold higher than that of normal PMN and that the increase occurs among all of the PMN (34). To determine if tolerance to endotoxin-induced synthesis of IL- $1 \beta$ and increased constitutive expression of IL-1R2 are concomitantly present in sepsis PMN, we evaluated both synthesis of IL- $1 \beta$ and expression of IL-1R2 in seven patients. All sepsis PMN with reduced synthesis of IL- $1 \beta$ had enhanced expression of IL-1R2, measured as sites per cell by saturation binding of ${ }^{125} \mathrm{I}$ IL-1 $\alpha$ (Fig. 5).

Levels of IL-1 $\mathrm{mRNA}$ in sepsis and normal PMN. To determine if reduced synthesis of IL- $1 \beta$ was related at least in part to a decrease in expression of the IL-1 $\beta$ gene, we quantified IL- $1 \beta$ mRNA in sepsis PMN. Fig. 6 shows a representative

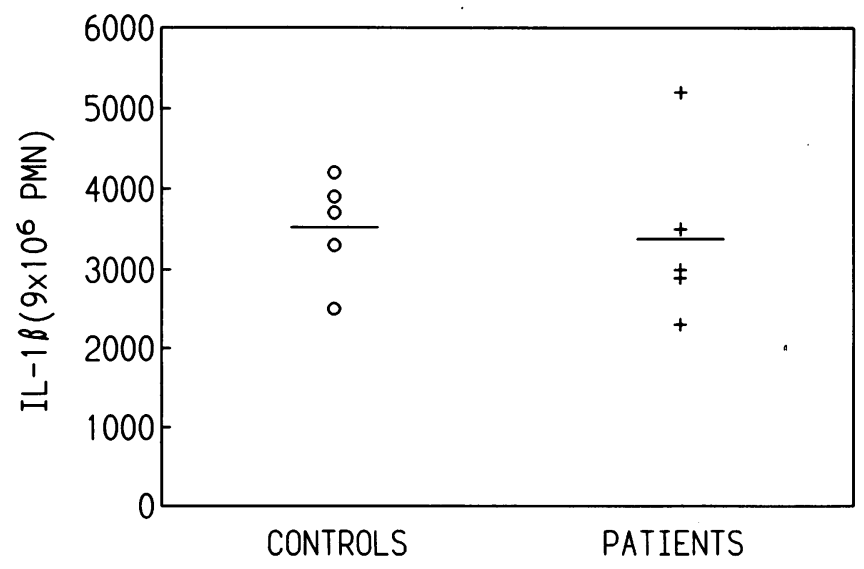

Figure 4. Synthesis of IL-1 $\beta$ in sepsis versus normal PMN after stimulation with $S$. aureus. Isolated PMN were stimulated for $8 \mathrm{~h}$ at $37^{\circ} \mathrm{C}$ with $S$. aureus at a ratio of $\sim 20$ microbes to 1 PMN and IL-1 $\beta$ measured by ELISA. The horizontal line represents the mean of each group. $P>0.3$ by the paired $t$ test. 


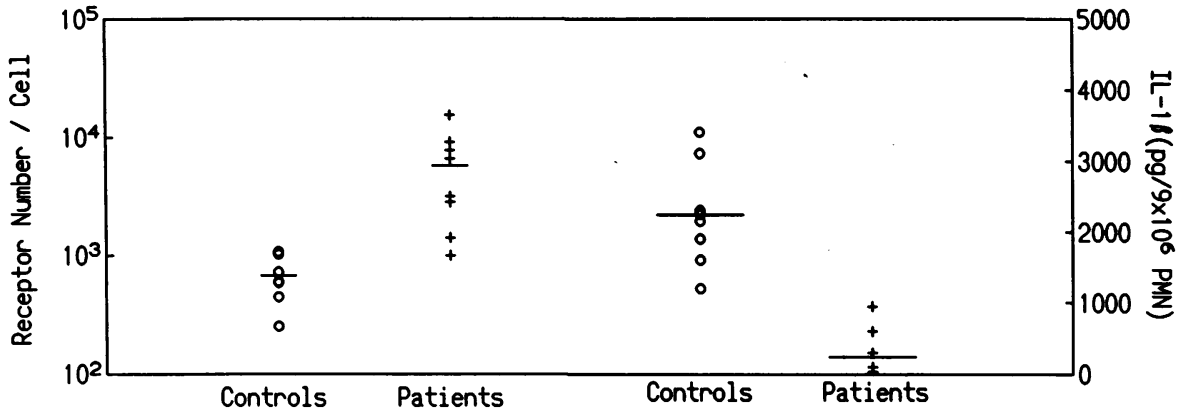

Figure 5. Tolerance to endotoxin-induced synthesis of IL- $1 \beta$ and enhanced expression of the IL-1R2 occur concomitantly in sepsis PMN. Synthesis of IL- $1 \beta$ was performed as described in Fig. 1. Quantitation of ILIR2 expressed as sites per cell was determined by saturation binding of ${ }^{125}$ I-IL-1 $\alpha$ and Scatchard analysis. All sepsis PMN tolerant to endotoxin-induced synthesis of IL-1 $\beta$ had concomitant increases in expression of IL-1R2. The $K_{\mathrm{d}}$ of sepsis and normal PMN were similar at $\sim 1.0 \mathrm{nM}$ (not shown). experiment from seven. All preparations of sepsis PMN studied had a quantity of IL- $1 \beta$ mRNA below that of normal PMN, when signals were corrected for $\beta$ actin or quantity of mRNA loaded per lane (sepsis PMN mean was $24 \pm 19 \%$ SD of control, $P<0.001)$. Sepsis PMN could not increase their steady state IL-1 $\beta$ mRNA at earlier $(1 \mathrm{~h})$ or later $(4 \mathrm{~h})$ time points (data not shown).

Elastase secretion by sepsis versus normal PMN. To determine if a rapid or early functional response of PMN to another receptor-mediated agonist is altered during the sepsis syndrome, we determined the rate of elastase secretion after stimulation of normal and sepsis PMN with $1 \times 10^{-6} \mathrm{M}$ FMLP in the presence of $5 \mu \mathrm{g} / \mathrm{ml}$ of cytochalasin B. Sepsis PMN from three patients whose PMN were tolerant to endotoxin-induced synthesis of IL-1 $\beta$ were evaluated; none of these had a decrease in elastase secretion (Table III).

Expression of CD14 on sepsis versus normal PMN. Both PMN and monocytes functionally respond to stimulation by endotoxin at least in part via the CD14 glycosylphosphoinositol-anchored membrane protein (44-46). To determine if endotoxin tolerance is associated with a loss of expression of this receptor, we evaluated CD14 in nine sepsis PMN versus nine normal PMN. We determined in parallel that the sepsis PMN were tolerant to endotoxin-induced IL- $1 \beta$ synthesis or increases in IL-1 $\beta$ mRNA. No differences between sepsis and normal PMN were detected in the mean fluorescence intensity

\section{$\mathbf{I L}-1 \beta$}

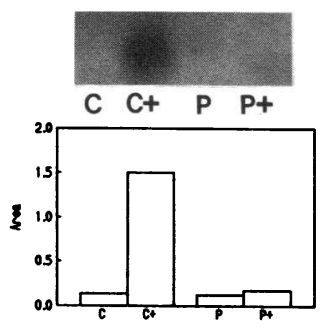

\section{$\beta$-Actin}

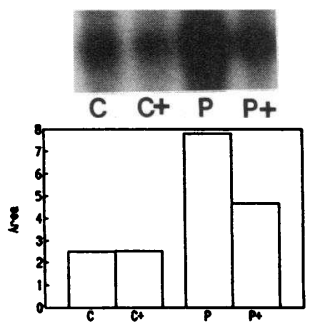

Figure 6. Levels of IL$1 \beta$ mRNA in sepsis versus normal PMN after stimulation with endotoxin. PMN were incubated with or without $100 \mathrm{ng} / \mathrm{ml}$ of 0111:B4 $E$. coli endotoxin for $1.5 \mathrm{~h}$ at $37^{\circ} \mathrm{C}$ and affinity-purified mRNA probed by Northern analysis with antisense RNA probes to IL- $1 \beta$ and a CDNA probe to $\beta$-actin. One of seven experiments is demonstrated, all of which showed a reduction in endotoxin-induced IL$1 \beta$ mRNA in sepsis PMN. measured by binding of two different monoclonal antibodies to CD14, MY-4 and Leu M3. MY 4 gave a stronger signal than Leu M3 and the results using this antibody are shown in Fig. 7, but both antibodies could detect CD14 and gave similar results in sepsis versus normal PMN. Using the MY 4 antibody, the mean fluorescence (in $\log$ units) of sepsis PMN was 163 as compared with 171 in control PMN $(P>0.5)$ by the paired $t$ test).

Analysis of clinical data. In reviewing patient characteristics, no correlation was found between the magnitude of the tolerance to endotoxin-induced synthesis of IL- $1 \beta$ and patient age, sex, race, temperature, total white blood cell, absolute PMN count, presence of immature forms of PMN (range $<5$ to $>30 \%$ ), presence of hypotension ( septic shock was present in $86 \%$ of patients), metabolic acidosis, adult respiratory distress syndrome $(81 \%)$, number of organs in failure, microorganism responsible for infection (Gram-positive, Gram-negative bacteria, mixed Gram-positive and Gram-negative, Candida species, staphylococcal exotoxin, rickettsia were presumed causes), location of infection, presence of bacteremia $(46 \%)$, use of vasopressors, or mortality ( $50 \%)$. A reduction in tolerance was not observed among the patients that survived. There was no apparent relationship between tolerance to endotoxin and the time blood samples were obtained with respect to onset of the sepsis syndrome. The earliest that a patient was studied after onset of the sepsis syndrome was $\sim 8 \mathrm{~h}$, but most patients were first investigated within $72 \mathrm{~h}$ of the onset of organ failure.

\section{Discussion}

This study shows that sepsis PMN do not constitutively produce IL- $1 \beta$ and are consistently tolerant to endotoxin-induced

Table III. Secretion of Elastase by Sepsis versus Normal PMN

\begin{tabular}{ccc}
\hline Patient & Control mean & Patient mean \\
\hline 1 & 166 & 196 \\
2 & 173 & 347 \\
3 & 305 & 184 \\
Total mean \pm SD & $215 \pm 45.2$ & $243 \pm 52.2$
\end{tabular}

PMN were stimulated with $10^{-6} \mathrm{M}$ FMLP for $5 \mathrm{~min}$ at $37^{\circ} \mathrm{C}$ in the presence of $5 \mu \mathrm{g} / \mathrm{ml}$ cytochalasin B and with release of elastase continuously monitored by spectrofluorometry. Values represent mean $\pm \mathrm{SD}$ of the maximum slope. There is no significant difference between the means. 


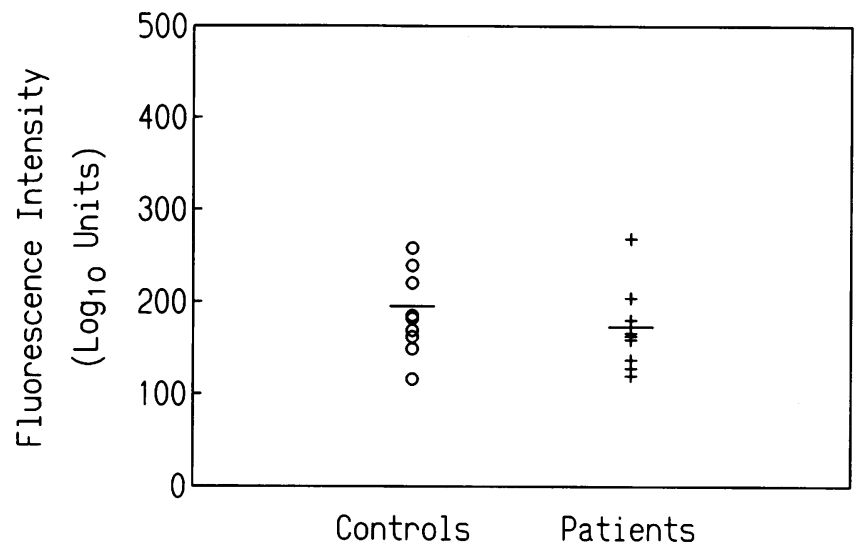

Figure 7. Expression of $\mathrm{CD} 14$ receptor for endotoxin on sepsis versus normal PMN. Fluorescence of nine normal $\operatorname{PMN}(A)$ or nine sepsis PMN $(B)$ expressed in log units was measured by flow cytometry using the phycoerythrin-conjugated mouse monoclonal antibody (MY $4)$ to human CD14. All values are corrected for the fluorescence observed using an IgG2a isotype control antibody. Results were similar when the Leu M3 monoclonal antibody to CD14 was used (not shown).

expression of the IL- $1 \beta$ gene as defined by combined reductions in endotoxin-stimulated levels of IL- $1 \beta$ mRNA and immunoreactive IL-1 $\beta$. This tolerance of sepsis PMN to endotoxin occurs concomitant with the enhanced expression of the IL-1R2 that we previously reported (34). Tolerance specifcally involves the endotoxin signal transduction path since sepsis PMN respond normally to $S$. aureus induction of IL- $1 \beta$ synthesis. This phenotypic alteration in sepsis PMN is not limited to infection by Gram-negative bacteria; it is also seen when the sepsis syndrome is apparently induced by Gram-positive bacteria, rickettsia, candida species, or staphylococcal exotoxins. Although we have not shown that suppressed expression of the IL- $1 \beta$ gene in fesponse to endotoxin and increased expression of IL-1R2 occur in the same population of PMN, this is likely since the enhanced expression of IL-1R2 in sepsis PMN is a unimodal event (34). Both tolerance to endotoxin and enhanced expression of IL-1R2 return to normal in PMN of patients who recover from the sepsis syndrome. Tolerance is not predictive of the type or number of organs failing or the mortality, which was high in this group of patients despite the presence of tolerance.

The correlation between tolerance to endotoxin-induced IL- $1 \beta$ gene expression and increased expression of IL-1R2 is striking in that we observed both events in all nine patients in which the assays were performed concomitantly. In preliminary studies, we have found that the steady state level of ILIR2 mRNA is consistently elevated in sepsis PMN (Crater, D. and C. E. McCall, unpublished observations). This raises the possibility that increased IL-1 R2 expression and decreased ability to express the IL- $1 \beta$ gene may be causally related and perhaps represent the effects of one or more counter-regulatory signals on sepsis PMN. There is precedent for this idea. Signals that amplify expression of IL-1R2 in monocytes, as well as IL-1 R1 in T lymphocytes, can suppress synthesis of IL-1. One such candidate is glucocorticoid hormone, a mediator that is typically elevated during severe infection $(47,48)$. The synthetic adrenocorticosteroid dexamethasone enhances expression of IL-1R2 and blocks synthesis of IL-1 in human mono- cytes $(49,50)$. Glucocorticoids can also increase expression of IL-1R2 in human blood PMN when administered in vivo (unpublished observations) or in vitro (Spriggs M., personal communication ). Shieh et al. (51) recently reported that glucocorticoid and granulocyte colony stimulating factor synergistically amplify expression of IL-1R2 on mouse PMN in vitro and in vivo. The up-regulation of IL-1R2 on mouse PMN induced by these two agents required de novo synthesis of the receptor by mature cells. We reported that another colony stimulating factor, granulocyte macrophage colony-stimulating factor, induces de novo synthesis of IL-1R2 in normal human PMN (13). Prostaglandin $E_{2}$ is another mediator that can suppress synthesis of cytokines and enhance expression of IL-1R2 in monocytes $(49,52)$. It is possible that one or more of these agents is responsible for inducing the alterations in both IL1 R2 and IL- $1 \beta$ gene expression in sepsis PMN. For example, levels of circulating glucocorticoids are known to be elevated in states of severe infection (1). Stimulation of IL-1R2 by IL-1 does not activate immediate responses of PMN, and IL-1R2 can be shed from Raji B lymphocytes (53). This suggests that IL-1R2 might play a protective role in inflammatory states where high levels of IL-1 could be autotoxic.

Munoz et al. (32) recently reported that adherent monocytes from patients with the sepsis syndrome are tolerant to endotoxin-induced synthesis of IL- $1 \alpha$ and $-\beta$, TNF $\alpha$, and IL-6, but no studies of cytokine mRNA were included in that report. That study, like ours, found that endotoxin tolerance of sepsis monocytes occurred in patients infected with both Gram-positive and Gram-negative bacteria. Another similarity between the study of Munoz et al. and ours is that tolerance of sepsis monocytes to endotoxin did not correlate with any of the laboratory parameters analyzed or with the severity of the illness, although endotoxin tolerance persisted in monocytes of patients that expired (32). Both studies suggest that tolerance to endotoxin is a consistent phenotypic feature of blood phagocytes of patients with the sepsis syndrome, regardless of its cause.

Both the study of Munoz et al. (32) and ours also suggest that tolerance to endotoxin may have specificity for the organ failure syndrome associated with the severe inflammation and sepsis. Severely ill patients from various causes (e.g., physical trauma, burn injury, hypotension from volume depletion, or myocardial failure) appear not to be associated with endotoxin tolerance unless severe inflammation is a concurrent event ( Table II). Our finding of marked elevation in expression of IL$1 R 2$ in sepsis PMN also had specificity for acute inflammation with concomitant organ failure (34). A recent study of bacterial and viral infections without organ failure found that endotoxin-induced synthesis of IL-1 in blood mononuclear cells from infected patients was equal to or above that observed in normal cells (54). It is tempting to conclude that tolerance to endotoxin induction of potentially autotoxic cytokines occurs only in the presence of organ failure. However, we emphasize that the data on specificity should be interpreted with caution and that a more rigorous investigation is needed to establish both the sensitivity and specificity of endotoxin tolerance (or other phenotypic changes of sepsis blood leukocytes) for the sepsis syndrome. We are presently performing such a study using whole blood rather than isolated cells, an approach that allows procurement of smaller samples of blood from extremely ill patients.

The molecular mechanisms responsible for adaptation or tolerance to endotoxin are unknown, but "early" tolerance is a 
cell-mediated event (18). Mathison et al. (30) demonstrated that tolerance to endotoxin induction of TNF $\alpha$ synthesis in rabbit peritoneal macrophages involves an inability of the cells to increase levels of TNF $\alpha$ mRNA. Tolerance to endotoxin in this model was also stimulus specific since normal synthesis of TNF $\alpha$ in macrophages occurred in response to $S$. aureus. Our findings in endotoxin-tolerant sepsis PMN are similar to the observation of Mathison et al., with reductions in steady state mRNA after stimulation of tolerant cells by endotoxin but with normal increases in IL- $1 \beta$ mRNA after stimulation with $S$. aureus. Haas et al. (28) reported that endotoxin tolerance of TNF $\alpha$ gene expression in the macrophage cell-line Mono-Mac 6 was associated with reductions of TNF $\alpha$ mRNA and that tolerance could be induced by activation of protein kinase $A$ and reversed by activation of protein kinase $C$. In that study, normal translocation and binding of the transcriptional enhancer $\mathrm{NF}_{\kappa} \mathrm{B}$ was found, suggesting that the decrease in $\mathrm{TNF} \alpha$ mRNA in these endotoxin-tolerant cells was a posttranscriptional event. Our findings and those of Mathison et al. (30) are compatible with that thesis. In contrast, Zuckerman et al. (27) found that tolerance to endotoxin-induced secretion of TNF $\alpha$ in thioglycolate-elicited murine peritoneal macrophages was dependent on post-translational regulatory processes that prevented maturation and secretion of the higher relative molecular mass TNF $\alpha$ precursor protein. Decreased GTPase activity has also been implicated in tolerance of macrophages to endotoxin (55). The differences noted among these studies may indicate that endotoxin-responsive cells can adapt to endotoxin in several ways and that the mechanism responsible for tolerance varies among cell types or animal species.

Although we have not identified the precise mechanism responsible for tolerance of sepsis $\mathrm{PMN}$ to endotoxin, the tolerance may follow reduced synthesis or enhanced degradation of IL- $1 \beta$ mRNA. The mechanism by which endotoxin alters the steady state level of IL- $1 \beta$ mRNA is unknown, but both increased transcription and stabilization of IL- $1 \beta$ mRNA occur when IL- $1 \beta$ synthesis is induced in human PMN by IL- $1 \alpha$ or TNF $\alpha$ (56). The IL- $1 \beta$ gene (as analyzed using GenBanK) contains consensus sequences that could bind enhancing transcription factors such as $\mathrm{NF} \kappa \mathrm{B}$ or AP-1 or repressors such as heat shock proteins at its $5^{\prime}$ untranslated region; the 3 ' untranslated region of the IL- $1 \beta$ gene contains $A+U$-rich elements that appear to regulate degradation of mRNA of rapid response genes such as TNF $\alpha$ and GM-CSF (57). One or more of these $5^{\prime}$ or $3^{\prime}$ sequences might be involved in regulating IL- $1 \beta$ mRNA in PMN stimulated by endotoxin. Further research is needed to determine whether there are specific alterations in the $5^{\prime}$ or $3^{\prime}$ events that regulate levels of IL- $1 \beta$ mRNA in sepsis versus normal PMN.

The prenuclear intracellular signals that regulate the response of PMN to endotoxin stimulation are also poorly understood. However, recent reports indicate that the initial signaling for some functional responses of human PMN and monocytes requires the recognition of a complex of endotoxin and a lipopolysaccharide-binding plasma protein (LBP) ${ }^{1}$ by the CD14 membrane protein $(45,46,58,59)$. This mechanism is involved in endotoxin stimulation of the TNF $\alpha$ gene in monocytes (45). We have found that endotoxin-induced expression of the IL- $1 \beta$ gene in normal human PMN absolutely requires binding of endotoxin and LBP to the CD14 receptor

1. Abbreviation used in this paper: LBP, lipopolysaccharide-binding protein.
(LaRue, K., and C. McCall, manuscript in preparation). The CD14 receptor is anchored to the external membrane by a glycosylphosphatidylinositol linkage (60). Human monocytes release CD14 from their surfaces after in vitro stimulation with a variety of agonists, a process apparently controlled by a protease and not by a phospholipase (61). Elevations of soluble CD14 have been found in plasma of patients with burn and trauma injury (62), suggesting that inflammatory processes may induce release of CD14. However, a quantitative deficiency of CD14 on sepsis PMN does not explain endotoxin tolerance in sepsis PMN, since these cells and normal PMN express similar levels of CD14 as determined by FACS analysis. It is still possible that CD14 receptors expressed on sepsis PMN do not bind the complex of endotoxin and LBP normally or that CD14 receptors are uncoupled from intracellular signals required for gene expression. It is also possible that sepsis PMN rapidly deacylate and thereby inactivate endotoxin $(63,64)$. Another possibility is that PMN inhibit endotoxin by the bactericidal/permeability-increasing protein that is located in their primary granules $(65)$. This protein could compete with the serum LBP for binding of endotoxin. Deacylation of endotoxin or its inactivation by bactericidal/permeability-increasing protein are less plausible explanations for tolerance since sepsis PMN cannot respond to very high concentrations of endotoxin (Fig. 3).

Tolerance to endotoxin does not represent a global suppression of the functional ability of sepsis PMN. The response of sepsis PMN to stimulation of IL- $1 \beta$ synthesis by $S$. aureus is normal in sepsis PMN and sepsis PMN normally secrete elastase. We have found, however, that sepsis PMN have a consistent and specific decrease in both the $\mathrm{p} 47$ phox and p67 phox cytoplasmic components of NADPH oxidase and that sepsis PMN with reductions in these two proteins have marked reductions in their ability to mount a respiratory burst when stimulated by either phorbol myristate acetate or FMLP (Leone, P., C. E. McCall, and D. Bass, manuscript submitted for publication ).

Conclusions. The sepsis syndrome is consistently associated with specific alterations in the phenotype of circulating PMN, including a concomitant tolerance to endotoxin-induced expression of IL- $1 \beta$ and increased expression of IL-1R2. The precise mechanism responsible for endotoxin tolerance of sepsis PMN is unknown, but it results in the inability of sepsis PMN to increase the steady-state level of IL- $1 \beta$ mRNA when they are specifically stimulated by endotoxin. The tolerance to endotoxin appears to have specificity since endotoxin-tolerant sepsis PMN can respond normally to stimulation of IL- $1 \beta$ synthesis by $S$. aureus. Tolerance occurs during the course of infection by Gram-positive, Gram-negative, and fungal microorganisms and it is not present in patients seriously ill without detectable infection. Tolerance to endotoxin is not related to loss of the CD14 endotoxin receptor nor is it the result of a global reduction in functional responses of PMN. Since PMN can injure tissue by their ability to synthesize potentially autotoxic cytokines, such as IL- 1 and TNF $\alpha$, and to produce toxic oxygen species, it is possible that tolerance to endotoxin (by suppressing cytokine synthesis), enhanced expression of IL-1R2 and TNF $\alpha$ R (possibly by enhancing removal of these cytokines from circulation ), and downregulation of specific components of the respiratory burst enzyme NADPH oxidase (by reducing toxic oxygen species) are attempts by the host to protect itself against the adverse effects of disseminated intravascular inflammation. 


\section{Acknowledgments}

We thank Jane Sinclair for procuring patients for this study, Mary Green for administrative and secretarial assistance, Sara Neal for radiolabelling IL-1, and Betsy Gregory and Stewart Roten for performing the FACS ${ }^{\circledR}$ analysis. We are especially grateful to Steve Gillis and Steve Dower and Peter Lomedico who supplied us with the reagents as identified in the text.

This work was supported by National Institutes of Health grants AI-09169 and HL-29293 to C. E. McCall, CA-12197, which supports the Flow Cytometry Core Facility of the Comprehensive Cancer Center of Wake Forest University, and 1-MO1-RR07122, which supports the General Clinical Research Center.

\section{References} 469.

1. Bone, R. C. 1991. The pathogenesis of sepsis. Ann. Intern. Med. 115:457-

2. Martin, M. A., R. P. Wenzel, and K. J. Gorelick. 1991. Gram-negative bacterial sepsis in hospitals in the United States-natural history in the 1980s. Prog. Clin. Biol. Res. 367:111-119.

3. Parrillo, J. E., M. M. Parker, C. Natanson, A. F. Suffredini, R. L. Danner, R. E. Cunnion, and F. P. Ognibene. 1990. Septic shock in humans: advances in the understanding of pathogenesis, cardiovascular dysfunction, and therapy. Ann. Intern. Med. 113:227-242.

4. Ziegler, E. J., C. J. Fisher, Jr., C. L. Sprung, R. C. Straube, J. C. Sadoff, G. E. Foulke, C. H. Wortel, M. P. Fink, R. P. Dellinger, N. N. H. Teng, et al. 1991. Treatment of gram-negative bacteremia and septic shock with HA-1A human monoclonal antibody against endotoxin-a randomized, double-blind, placebocontrolled trial. N. Engl. J. Med. 324:429-436.

5. Greenman, R. L., R. M. H. Schein, M. A. Martin, R. P. Wenzel, N. R. MacIntyre, G. Emmanuel, H. Chmel, R. B. Kohler, M. McCarthy, J. Plouffe, et al. 1991. A controlled clinical trial of E5 murine monoclonal IgM antibody to endotoxin in the treatment of gram-negative sepsis. JAMA (J. Am. Med. Assoc.) 266:1097-1102.

6. Bone, R. C. 1991. A critical evaluation of new agents for the treatment of sepsis. JAMA (J. Am. Med. Assoc.). 266:1686-1691.

7. Tracey, K. J., S. F. Lowry, and A. Cerami. 1988. Cachetin/TNF- $\alpha$ in septic shock and septic adult respiratory distress syndrome. Am. Rev. Respir. Dis. 138:1377-1379.

8. Cannon, J. G., R. G. Tompkins, J. A. Gelfand, H. R. Michie, G. G. Stanford, J. W. M. Van der Meer, S. Endres, G. Lonnemann, J. Corsetti, B. Chernow, et al. 1990. Circulating interleukin-1 and tumor necrosis factor in septic shock and experimental endotoxin fever. J. Infect. Dis. 161:79-84.

9. Hack, C. E., E. R. De Groot, R. J. F. Felt-Bersma, J. H. Nuijens, R. J. M. S Van Schijndel, A. J. M. Eerenberg-Belmer, L. G. Thijs, and L. A. Aarden. 1989. Increased plasma levels of interleukin-6 in sepsis. Blood. 74:1704-1710.

10. Heremans, H., J. V. Damme, C. Dillen, R. Dijkmans, and A. Billiau. 1990. Interferon gamma, a mediator of lethal lipopolysaccaride-induced Shwartzman-like shock reactions in mice. J. Exp. Med. 171:1853-1869.

11. Van Zee, K. J., L. E. DeForge, E. Fischer, M. A. Marano, J. S. Kenney, D. G. Remick, S. F. Lowry, and L. L. Moldawer. 1991. IL-8 in septic shock, endotoxemia, and after IL-1 administration. J. Immunol. 146:3478-3482.

12. Dinarello, C. A. 1991. The proinflammatory cytokines interleukin-1 and tumor necrosis factor and treatment of the septic shock syndrome. J. Infect. Dis. 163:1177-1184

13. Lord, P. C., L. M. Wilmoth, S. B. Mizel, and C. E. McCall. 1991. Expression of interleukin-1 alpha and beta genes by human blood polymorphonuclear leukocytes. J. Clin. Invest. 87:1312-1321.

14. Dubravec, D. B., D. R. Spriggs, J. A. Mannick, and M. L. Rodrick. 1990 Circulating human peripheral blood granulocytes synthesize and secrete tumo necrosis factor $\alpha$. Proc. Natl. Acad. Sci. USA. 87:6758-6761.

15. Olson, N. C., W. L. Salzer, and C. E. McCall. 1988. Biochemical, physiological and clinical aspects of endotoxemia. Mol. Aspects. Med. 10:511-629.

16. Beeson, P. B. 1947. Tolerance to bacterial pyrogens. J. Exp. Med. 86:29

17. Johnston, C. A., and S. E. Greisman. 1985. Mechanism of endotoxin tolerance. Handb. Endotoxin. 2:359-401.

18. Greisman, S. E., R. B. Hornick, F. A. Carozza, and T. E. Woodward. 1964. Endotoxin tolerance. J. Clin. Invest. 43:986-999.

19. Greisman, S. E., E. J. Young, and F. A. Carozza. 1969. Mechanisms of endotoxin tolerance. V. Specificity of the early and late phases of pyrogenic tolerance. J. Immunol. 103:1223-1236.

20. Beutler, B., N. Krochin, I. W. Milsark, C. Leudke, and A. Cerami. 1986. Control of cachectin (tumor necrosis factor) synthesis: mechanisms of endotoxin tolerance. Science (Wash. DC). 232:977-980.

21. Wallach, D., H. Holtmann, H. Englemann, and Y. Nophar. 1988. Sensiti- zation and desensitization to lethal effects of tumor necrosis factor and IL-1. $J$. Immunol. 140:2994-2999.

22. Vogel, S. N., E. N. Kaufman, M. D. Tate, and R. Neta. 1988. Recombinant interleukin-la and recombinant tumor necrosis factor a synergize in vivo to induce early endotoxin tolerance and associated hematopoietic changes. Infect. Immun. 56:2650-2657.

23. Alexander, H. R., B. C. Sheppard, J. C. Jensen, H. N. Langstein, C. M. Buresh, D. Venzon, E. C. Walker, D. L. Fraker, M. C. Stovroff, and J. A. Norton. 1991. Treatment with recombinant human tumor necrosis factor-alpha protects rats against the lethality, hypotension, and hypothermia of gram-negative sepsis. J. Clin. Invest. 88:34-39.

24. Fraker, D. L., M. C. Strovroff, M. J. Merino, and J. A. Norton. 1988. Tolerance to tumor necrosis factor in rats and the relationship to endotoxin tolerance and toxicity. J. Exp. Med. 168:95-105.

25. Neta, R., J. J. Oppenheim, R. D. Schreiber, R. Chizzonite, G. D. Ledney, and T. J. MacVittie. 1991. Role of cytokines (interleukin 1, tumor necrosis factor, and transforming growth factor $\beta$ ) in natural and lipopolysaccharide-enhanced radioresistance. J. Exp. Med 173:1177-1182.

26. Haas, J. G., C. Thiel, K. Blömer, E. H. Weiss, G. Riethmüller, and H. W. L. Ziegler-Heitbrock. 1989. Downregulation of tumor necrosis factor expression in the human Mono-Mac-6 cell line by lipopolysaccharide. J. Leukocyte Biol. 46:11-14.

27. Zuckerman, S. H., G. F. Evans, Y. M. Snyder, and W. D. Roeder. 1989 Endotoxin-macrophage interaction: post-translational regulation of tumor necrosis factor expression. J. Immunol. 143:1223-1227.

28. Haas, J. G., P. A. Baeuerle, G. Riethmüller, and H. W. L. Ziegler-Heitbrock. 1990. Molecular mechanisms in down-regulation of tumor necrosis factor expression. Proc. Natl. Acad. Sci. USA. 87:9563-9567.

29. Ziegler-Heitbrock, H. W. L., M. Blumenstein, E. Käfferlein, D. Kieper, I. Petersmann, S. Endres, W. A. Flegel, H. Northoff, G. Riethmüller, and J. G. Haas. 1992. In vitro desensitization to lipopolysaccharide suppresses tumour necrosis factor, interleukin-1 and interleukin- 6 gene expression in a similar fashion. Immunology. 75:264-268.

30. Mathison, J. C., G. D. Virca, E. Wolfson, P. S. Tobias, K. Glaser, and R. J. Ulevitch. 1990. Adaptation to bacterial lipopolysaccharide controls lipopolysaccharide-induced tumor necrosis factor production in rabbit macrophages. J. Clin. Invest. 85:1108-1118.

31. Zuckerman, S. H., and G. F. Evans. 1992. Endotoxin tolerance: in vivo regulation of tumor necrosis factor and interleukin-1 synthesis is at the transcriptional level. Cell. Immunol. 140:513-519.

32. Munoz, C., J. Carlet, C. Fitting, B. Misset, J.-P. Bleriot, and J.-M. Cavallon. 1991. Dysregulation of in vitro cytokine production by monocytes during sepsis. J. Clin. Invest. 88:1747-1754.

33. Heliminen, M., and T. Vesikari. 1990. Interleukin-1 production in bacterial meningitis. Scand. J. Infect. Dis. 22:105-108.

34. Fasano, M. B., S. Cousart, S. Neal, and C. E. McCall. 1991. Increased expression of the interleukin 1 receptor on blood neutrophils of humans with the sepsis syndrome. J. Clin. Invest. 88:1452-1459.

35. Bower, W. F., and C. E. McCall. 1991. Differential expression of receptors for tumor necrosis factor (TNF) and complement CR3 on blood neutrophils of patients with the sepsis syndrome. Clin. Res. 38:351a. (Abstr.)

36. Bone, R. C. 1991. Sepsis, the sepsis syndrome, multi-organ failure: a plea for comparable definitions. Ann. Intern. Med. 114:332-333.

37. Ausubel, F. M., R. Brent, R. E. Kingston, D. D. Moore, J. G. Seidman, J. A. Smith, and K. Struhl. 1990. Current Protocols in Molecular Biology. Greene Publishing Associates and Wiley-Interscience, New York.

38. Promega Corporation. 1991. Promega Protocols and Applications Guide. Promega Corporation, Madison, WI. $60 \mathrm{pp}$

39. Virca, G. D., W. Northermann, B. R. Sheils, G. Widera, and S. Broome. 1990. Simplified Northern blot hybridization using $5 \%$ sodium dodecyl sulfate. Biotechniques. 8:370-371.

40. Paganelli-Parker, K., W. R. Benjamin, K. L. Kaffka, and P. L. Kilian. 1989. Presence of IL-1 receptors on human and murine neutrophils: relevance to IL-1-mediated effects in inflammation. J. Immunol. 142:537-542.

41. Couturier, C., N. Haeffner-Cavaillon, M. Caroff, and M. D. Kazatchkine. 1991. Binding sites for endotoxins (lipopolysaccharides) on human monocytes. J. Immunol. 147:1899-1904.

42. Sklar, L. A., V. M. McNeil, A. J. Jesaitis, R. G. Painter, and C. G. Cochrane. 1982. A continuous, spectroscopic analysis of the kinetics of elastase secretion by neutrophils. The dependence of secretion upon receptor occupancy. J. Biol. Chem. 257:5471-5475.

43. Le Gall, J. R., P. Loirat, A. Alperovitch, C. Glaser, C. Granthil, D. Mathieu, P. Mercier, R. Thomas, and D. Villers. 1984. A simplified acute physiologic score for ICU patients. Crit. Care Med. 12:975-982.

44. Schumann, R. R., S. R. Leong, G. W. Flaggs, P. W. Gray, S. D. Wright, J. C. Mathison, P. S. Tobias, and R. J. Ulevitch. 1990. Structure and function of lipopolysaccharide binding protein. Science (Wash. DC). 249:1429-1431.

45. Wright, S. D., R. A. Ramos, P. S. Tobias, R. J. Ulevitch, and J. C. Mathison. 1990. CD14, a receptor for complexes of lipopolysaccaride (LPS) and LPSbinding protein. Science (Wash. DC). 249:1431-1434. 
46. Wright, S. D., R. A. Ramos, A. Hermanowski-Vosatka, P. Rockwell, and P. A. Detmers. 1991. Activation of the adhesive capacity of CR3 on neutrophils by endotoxin: dependence on lipopolysaccharide binding protein and CD14. $J$. Exp. Med. 173:1281-1286.

47. Romijn, J. A., M. H. Godfried, C. Wortel, and H. P. Sauerwein. 1990. Hypoglycemia, hormones and cytokines in fatal meningococcal septicemia. $J$. Endocrinol. Invest. 13:743-747.

48. Dennhardt, R., H.-J. Gramm, K. Meinhold, and K. Voigt. 1989. Patterns of endocrine secretion during sepsis. Prog. Clin. Biol. Res. 308:751-756.

49. Spriggs, M. K., P. J. Lioubin, J. Slack, S. K. Dower, U. Jonas, D. Cosman J. E. Sims, and J. Bauer. 1990. Induction of an interleukin-1 receptor (IL-1R) on monocytic cells. Evidence that the receptor is not encoded by a T cell-type IL-1R mRNA. J. Biol. Chem. 265:22499-22505.

50. Lew, W., J. J. Oppenheim, and K. Matsushima. 1988. Analysis of the suppression of IL-1 and IL-1 production in human peripheral blood mononuclear adherent cells by a glucocorticoid hormone. J. Immunol. 140:1895-1902.

51. Shieh, J. H., R. H. Peterson, and M. A. Moore. 1991. IL-1 modulation of cytokine receptors on bone marrow cells. In vitro and in vivo studies. J. Immunol. 147:1273-1278.

52. Kunkel, S. L., M. Spengler, M. A. May, R. Spengler, J. Larrick, and D. Remick. 1988. Prostaglandin E2 regulates macrophage-derived tumor necrosis factor gene expression. J. Biol. Chem. 263:5380-5384.

53. Giri, J. G., R. C. Newton, and R. Horuk. 1990. Identification of soluble interleukin-1 binding protein in cell-free supernatants. Evidence for soluble interleukin-1 receptor. J. Biol. Chem. 265:17416-17419.

54. Helminen, M., and T. Vesikari. 1987. Spontaneous and inducible interleukin-1 production from peripheral blood monocytes in bacterial and viral infections in children. Pediatr. Infect. Dis. J. 6:1102-1110.

55. Coffee, K. A., P. V. Halushka, W. C. Wise, and J. A. Cook. 1990. Altered responses to modulators of guanine nucleotide binding protein activity in endotoxin tolerance. Biochim. Biophys. Acta. 1035:201-205.
56. Marucha, P. T., R. A. Zeff, and D. L. Kreutzer. 1991. Cytokine-induced II-1B gene expression in the human polymorphonuclear leukocyte: transcriptional and post-transcriptional regulation by tumor necrosis factor and IL-1. $J$. Immunol. 147:2603-2608.

57. Caput, D., B. Beutler, K. Hartog, S. Brown-Shimer, and A. Cerami. 1986 Identification of a common nucleotide sequence in the 3'-untranslated region of mRNA molecules specifying inflammatory mediators. Proc. Natl. Acad. Sci. USA. 83:1670-1680.

58. Tobias, P. S., J. C. Mathison, and R. J. Ulevitch. 1988. A family of lipopolysaccharide binding proteins involved in responses to gram-negative sepsis. J. Biol. Chem. 263:13479-13481.

59. Wright, S. D., P. S. Tobias, R. J. Ulevitch, and R. A. Ramos. 1989. Lipopolysaccharide (LPS) binding protein opsonizes LPS-bearing particles for recognition by a novel receptor on macrophages. J. Exp. Med. 170:1231-1241.

60. Simmons, D. L., S. Tan, D. G. Tenen, A. Nicholson-Weller, and B. Seed. 1989. Monocyte antigen CD14 is a phospholipid anchored membrane protein. Blood. 73:284-289.

61. Bazil, V., and J. L. Strominger. 1991. Shedding as a mechanism of downmodulation of CD14 on stimulated human monocytes. J. Immunol. 147:15671574.

62. Kruger, C., C. Schutt, U. Obertacke, T. Joka, F. E. Muller, J. Knoller, M. Koller, W. Konig, and W. Schonfeld. 1991. Serum CD14 levels in polytraumatized and severely burned patients. Clin. Exp. Immunol. 85:297-301.

63. Erwin, A. L., and R. S. Munford. 1990. Deacylation of structurally diverse lipopolysaccharides by human acyloxyacylhydrolase. J. Biol. Chem. 265:1644416449.

64. Hampton, R. Y., and C. R. H. Raetz. 1991. Macrophage catabolism of lipid A is regulated by endotoxin stimulation. J. Biol. Chem. 266:19499-19509.

65. Eng Ooi, C., J. Weiss, M. E. Doerfler, and P. Elsbach. 1991. Endotoxinneutralizing properties of the $25 \mathrm{kD} \mathrm{N}$-terminal fragment and a newly isolated 30 kD C-terminal fragment of the 55-60 kD bactericidal/permeability-increasing protein of human neutrophils. J. Exp. Med. 174:649-655. 